\title{
Overweight and thinness in 7-9 year old children from Florianópolis, Southern Brazil: a comparison with a French study using a similar protocol
}

Sobrepeso e baixo peso em crianças de 7 a 9 anos de idade de Florianópolis, Sul do Brasil: uma comparação com estudo francês usando protocolo similar

Maria Alice Altenburg de ASSIS ${ }^{1}$

Marie Françoise ROLLAND-CACHERA ${ }^{2}$

Francisco de Assis Guedes de VASCONCELOS ${ }^{1}$

France BELLISLE²

Maria Cristina Marino CALVO ${ }^{3}$

Maria Elizabeth Peixoto LUNA ${ }^{4}$

Katia CASTELBON²

Suely GROSSEMAN ${ }^{5}$

Sanlina Barreto HÜLSE 6

A B S T R A C T

\section{Objective}

To assess nutritional status based on weight and height variables in children aged 7-9-y-old in a city from the South of Brazil (Florianópolis) and to compare the prevalence of thinness and overweight and environmental factors between Brazil and France.

\section{Methods}

Randomly stratified samples of 7-9 y-old children (Florianópolis, $n=2232$; France, $n=1582$ ). Both studies followed the protocol recommended by the European Childhood Obesity Group. Weight and height were

\footnotetext{
1 Departamento de Nutrição, Centro de Ciências da Saúde, Universidade Federal de Santa Catarina. Caixa Postal 476, Campus Universitário, Trindade, Florianópolis, SC, Brasil. Correspondência para/Correspondence to: M.A.A. ASSIS. E-mail: <massis@ccs.ufsc.br>.

2 Unité Mixte de Recherche U 557 INSERM/U 1125 INRA/CNAM/Paris 13, CRNH Ile de France, Paris, France.

3 Departamento de Saúde Pública, Centro de Ciências da Saúde, Universidade Federal de Santa Catarina. Florianópolis, SC, Brasil.

4 Secretaria da Saúde, Prefeitura Municipal de Florianópolis. Florianópolis, SC, Brasil.

5 Departamento de Pediatria, Centro de Ciências da Saúde, Universidade Federal de Santa Catarina. Florianópolis, SC, Brasil.

6 Secretaria da Educação, Prefeitura Municipal de Florianópolis. Florianópolis, SC, Brasil.
} 
recorded according to World Health Organization recommendation. Thinness and overweight were defined using the French references. Physical activity and sedentary behaviors were compared.

\section{Results}

Florianópolis children were taller and heavier than the French. The frequency of thinness was lower in Florianópolis as compared to France (1.1 vs 3.9\%). Overweight frequency was $19.9 \%$ in Florianópolis as compared to $16.3 \%$ in France. French children had a higher level of physical activity. In particular, $66.5 \%$ of French children had a regular sport activity compared to $35.7 \%$ in Florianópolis. In France, daily television and screen viewing time was 2 hours per day as compared to 3.3 hours in Brazil.

\section{Conclusion}

Behavioral parameters, particularly sedentary lifestyle, could account for the higher prevalence of overweight in Brazilian children. Strategies to decrease the prevalence of overweight in children should take into account the particularities of each country.

Indexing terms: Brazil; child; France; nutritional status; obesity; overweight.

\section{R E S U M O}

\section{Objetivo}

Avaliar o estado nutricional de crianças de sete a nove anos de idade de Florianópolis (Brasil) e comparar a prevalência de sobrepeso e baixo peso com um estudo realizado na França.

\section{Métodos}

Os dois estudos comparados consistiram em investigações transversais de amostras aleatórias estratificadas de crianças de sete a nove anos da idade (Florianópolis, $n=2.232$; França, $n=1.582$ ), delineados com base no protocolo recomendado pelo European Childhood Obesity Group. As medidas antropométricas (peso e estatura) foram coletadas de acordo com normas recomendadas pela Organização Mundial de Saúde. Na análise da prevalência de sobrepeso e baixo peso (magreza) usou-se a referência francesa. Compararam-se alguns fatores relacionados à prática de atividade física e comportamentos sedentários entre os dois estudos.

\section{Resultados}

As crianças de Florianópolis foram mais altas e apresentaram maior peso corporal que as francesas. A prevalência de baixo peso foi mais baixa em Florianópolis, comparando-se com a França (1.1 vs 3.9\%). A prevalência de sobrepeso foi de 19,9\% em Florianópolis e de 16,3\% na França. Certos tipos de comportamentos podem estar contribuindo para uma mais elevada prevalência de sobrepeso em Florianópolis, quando comparada à França. As crianças francesas apresentaram mais elevado nivel de atividade física: 66,5\% das crianças franceses realizavam atividade esportiva regular, quando comparados aos 35,7\% das crianças de Florianópolis. Na França, o tempo destinado a assistir televisão, jogar vídeo game e utilizar computador foi de duas horas por dia, enquanto no Brasil foi de 3,3 horas diárias.

\section{Conclusão}

Alguns fatores comportamentais, tais como nivel de atividade física, e sedentarismo podem explicar as diferenças encontradas. As estratégias visando à redução da prevalência do sobrepeso infantil devem levar em consideração as particularidades específicas de cada país.

Termos de indexação: Brasil; criança; França; estado nutricional; obesidade; sobrepeso.

\section{INTRODUCTION}

Surveys over the past two decades have consistently shown a dramatic increase in child overweight and obesity in some developed and developing countries ${ }^{1}$. The factors responsible for this increase are still not clearly identified.
Therefore there is great interest in carrying out parallel studies in different contexts.

In order to facilitate the development of comparative international studies, the European Childhood Obesity Group (ECOG) ${ }^{2}$ has proposed a protocol for the assessment of overweight 
frequency in children. A French study was published to present data based on this protocol in a population of children 7 to 9 years old ${ }^{3,4}$.

Following this work, and thanking the collaboration between the Institut National de la Santé et Recherche Médicale (INSERM), France, and the Universidade Federal de Santa Catarina, Brazil, a similar study, using an identical protocol, was carried out with children living in Florianópolis, Southern Brazil. The prevalence of thinness, overweight and obesity for 7-10-y-old children from Florianópolis, using two different definitions ${ }^{5,6}$ were published previously ${ }^{7}$.

In this article, we presented the prevalence of thinness and overweight for 7-9-y-old Florianópolis children, defined on the basis of the French references ${ }^{8}$ for the first time. In addition, behavioral observations were compared between Florianópolis and France. Data obtained using a comparable approach in very different contexts can thus be compared directly.

Data from Florianópolis provide a basis for comparisons with other regions of Brazil and with more developed countries, since this city has one of the highest Human Development Indices (HDI) of the country ${ }^{9}$.

\section{METHODS}

\section{Data and Study population}

Florianópolis is the capital of the state of Santa Catarina, in the south of Brazil. The city has a total area of $433 \mathrm{~km}^{2}$; its demographic density is $760 \mathrm{hab} / \mathrm{km}^{2}$; the population is 369,102 inhabitants (urban $94.1 \%$ ); life expectancy at birth is 72.8 years; infant mortality rate is $18.5 / 1000$ live births $s^{9,10}$.

Data were collected in the year 2002 in a representative sample of 3516 school children, from private and public elementary schools. The study design is described elsewhere ${ }^{7}$. Briefly, public and private elementary schools were randomly selected from a list of the schools stratified by geographic area. In each school selected, all classes were included and all the children from first to fourth grades were invited to participate. For comparison purposes with the French study, only Florianópolis children aged 7-9-y-old ( $n=2232$ ) were included in this article.

Parents gave written informed consent to their child's participation in the study which also received approval from the Committee on Human Studies of the Federal University of Santa Catarina.

The study in France was conducted in 2000 in similar conditions, with 1582 children aged 7-9-y-old, following the same ECOG protocol ${ }^{2,3}$.

\section{Measurements Body measurements}

Anthropometric measurements were taken in each school by trained health personnel and performed using standardized procedures ${ }^{11}$. Anthropometric measurements were performed in lightly dressed children, without shoes and included weight, height, middle upper arm circumference (MUAC), waist and hip circumferences, and four skinfold thicknesses. In the present article only the weight, height and BMI were analyzed. Height was measured using a metric tape fixed to a wall without a baseboard, with the child standing up, weight being equally distributed on both feet, and head, back and buttock on the vertical land on the height gauge. Weight was measured with calibrated portable scales with a precision of $100 \mathrm{~g}$. The body mass index (BMI) was computed as weight in $\mathrm{kg}$ divided by height in $\mathrm{m}^{2}$.

\section{Definition of thinness and overweight}

The Body Mass Index (BMI) is now used worldwide to assess nutritional status. It is based on weight and height which are easily available and reliable measurements, and it is closely correlated with total and percent body fat assessed 
by more fundamental measures of body composition. Because BMI varies during growth, BMI references are given by age and sex ${ }^{12}$.

Thinness and overweight were evaluated according to the French references. In 1982, based on the French data of the International growth study $^{13}$, the first BMI reference charts were constructed $^{14}$. They were subsequently revised in $1991^{8}$. From these references, thinness ( $\leq 3 \mathrm{rd}$ centile) and overweight (>97th centile) were defined. As opposed to the International Obesity Task Force cut offs ${ }^{6}$, defining overweight and obesity only, the French reference charts provide centile ranges from the $3^{\text {rd }}$ to the $97^{\text {th }}$ centile, allowing one to assess the prevalence of thinness, normal weight and overweight children.

\section{Physical activity and sedentary behaviors}

A complementary questionnaire was completed by the parents. It included information about themselves (anthropometric data, age, occupation and education level) and about the child (growth, early feeding, physical activity level, time spent watching TV, playing video games and using a computer). In this article, only data on the child's physical activity and sedentary behaviors were examined. Data on physical activity and sedentary behaviors were obtained for 1780 children aged 7-9-y-old (response rate: 79.7\%).

Physical activity was evaluated using three indicators, according to the parent's perception: 1) Active or inactive type of transport between home and school (active transport= walking and/or bike; inactive transport= car, bus, or motorcycle); 2) Sport performed outside school (yes/no) and 3) Child activity level. Parents were asked to rate their child's physical activity level as very active, active, not very active and inactive. For the analyses, activity levels were classified into two groups: active (very active and active) and non-active (not very active and inactive). Sedentary behavior was estimated using time spent watching TV, playing video games and using a computer. Parents were asked how many hours their children do these activities on a typical weekday.

\section{Analysis}

Statistical analyses were performed in children with complete information on age, school grade and anthropometric measurements. Children age $<7.0$ y and $\geq 10.0$ y were excluded. Three age groups were defined as follows: $7 y$ old $(7.0-7.9 \mathrm{y}), 8 \mathrm{y}$ old $(8.0-8.9 \mathrm{y})$ and $9 \mathrm{y}$ old (9.0 - $9.9 \mathrm{y})$.

Weight, height and BMI are presented as means with standard deviations by gender and age in Florianópolis and French studies. Between the studies, differences in mean values of anthropometric measurements were tested by analysis of variance. Values for physical activity indicators according to the parent's perception, were presented as frequencies. Sedentary behaviors (time spent watching TV, playing video games and using a computer) were given by gender and expressed as mean \pm standard deviations [(Mean (SD)], in a typical weekday. Gender differences were examined using the unpaired $t$-test.

Overall frequencies of thinness and overweight were computed by using direct standardization on age and gender. Comparisons of frequencies between ages or between genders were performed using the Mantel - Haenszel method and the chi-square test.

The significance level was set at $p<0.05$. Data were analyzed with SPSS 10.0 for Windows (SPSS Inc., 1999).

\section{RES U L T S}

Anthropometric characteristics and nutritional status in children from Florianópolis: comparison with French children. Table 1 presents anthropometric characteristics of Florianópolis and French children (weight, height, BMI) according to age and gender. 
Table 1. Comparisons of weight, height and BMI obtained from Florianópolis and French girls and boys aged 7-9-y-old 1 . (France, 2000; Florianópolis, 2002).

\begin{tabular}{|c|c|c|c|c|c|c|}
\hline \multirow[b]{2}{*}{ Age (y) } & \multicolumn{3}{|c|}{ Florianópolis (Brazil) } & \multicolumn{3}{|c|}{ France } \\
\hline & 7 & 8 & 9 & 7 & 8 & 9 \\
\hline Girls (n) & 328 & 386 & 372 & 253 & 401 & 142 \\
\hline \multicolumn{7}{|c|}{ Mean (SD) } \\
\hline Weight (kg) & $26.2(4.9)$ & $29.0(6.3)$ & $33.0(7.2)^{*}$ & $25.8(4.7)$ & $28.2(5.5)$ & $30.3(6.7)$ \\
\hline Height (cm) & $125.3(5.4)$ & $130.3(6.8)$ & $136.4(6.9)^{*}$ & $125.0(6.0)$ & $130.0(6.0)$ & $134.0(6.0)$ \\
\hline BMI $\left(\mathrm{kg} / \mathrm{m}^{2}\right)$ & $16.6(2.2)$ & $16.9(2.6)$ & $17.6(2.8)^{*}$ & $16.4(2.3)$ & $16.7(2.4)$ & $16.7(2.9)$ \\
\hline Boys (n) & 337 & 385 & 424 & 249 & 385 & 152 \\
\hline \multicolumn{7}{|c|}{ Mean (SD) } \\
\hline Weight (kg) & $26.9(4.9)$ & $30.3(6.6)^{*}$ & $33.2(7.7)^{*}$ & $26.1(4.7)$ & $29(5.7)$ & $26.1(6.4)$ \\
\hline Height (cm) & $126.5(5.9)$ & $131.6(6.3)^{\star}$ & $136.7(7.0)^{*}$ & $126.0(6.0)$ & $131.0(6.0)$ & $134.0(6.0)$ \\
\hline BMI $\left(\mathrm{kg} / \mathrm{m}^{2}\right)$ & $16.7(2.2)$ & $17.4(2.8)^{*}$ & $17.6(2.9)^{*}$ & $16.5(2.3)$ & $16.8(2.5)$ & $17(2.6)$ \\
\hline
\end{tabular}

*Significant difference between the studies in a given age group, $p<0.05$

In general, children from Florianópolis presented higher mean weight, height and BMI compared with French children. Differences increased with age. Florianopolis boys and girls aged 9-y-old were significantly heavier and taller compared to French children of the same age.

Age-standardized frequencies of thinness, normal weight and overweight estimated in 2232 children from Florianópolis and 1582 French children, according to the French references, are presented in Figure 1. No age or gender differences in the frequencies of thinness or overweight were observed in Florianópolis' children.

As a rule, overweight frequencies were higher for Florianópolis' children compared with the French sample, while frequency of thinness was higher in France, in all age groups. Differences in the prevalence of overweight were especially higher at age 8 years, for both girls $(21.8 \%$ in Florianópolis "versus" $18.7 \%$ in France) and boys (22.6\% in Florianópolis "versus" 12.7\% in France). For thinness frequencies, French values were especially higher at 9 -y-old, for both girls $(0.5 \%$ in Florianópolis "versus" 5.6\% in France) and boys (1.2\% in Florianópolis "versus" 5.9\% in France).

Table 2 presents mean times (hours/typical weekday) spent in sedentary behaviors (TV viewing, playing video game and using a

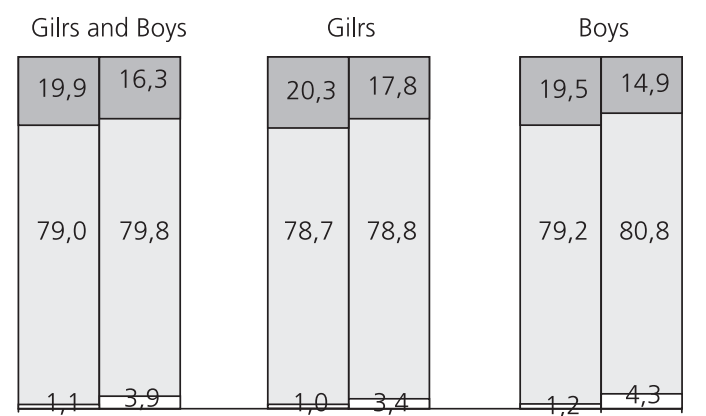

Florianópolis France Florianópolis France Florianópolis France
Thinness
Normal-weight
Overweight

Figure 1. Age- and gender-standardized frequencies of overweight, normal weight and thinness in 7 9-y-old children (girls and boys), and age standardized in girls and boys assessed on the basis of French references $^{8}$, in Florianópolis (1086 girls, 1146 boys) and France (796 girls, 786 boys). French data from Rolland-Cachera et al. ${ }^{3}$. (France, 2000; Florianópolis, 2002).

Table 2. Patterns of sedentary behaviors in Florianópolis schoolchildren by gender. [Mean (SD) hours of TV viewing, playing video games and using a computer in a typical weekday] (Florianópolis, 2002).

\begin{tabular}{lcccc}
\hline \multirow{2}{*}{$\begin{array}{l}\text { Sedentary } \\
\text { behavior }\end{array}$} & $\begin{array}{c}\text { All children } \\
(\mathrm{n}=1689)\end{array}$ & $\begin{array}{c}\text { Girls } \\
(\mathrm{n}=836)\end{array}$ & $\begin{array}{c}\text { Boys } \\
(\mathrm{n}=853)\end{array}$ & $p$ \\
\cline { 2 - 5 } & \multicolumn{4}{c}{ Mean (SD) } \\
\hline Television & $2.6(1.9)$ & $2.7(1.9)$ & $2.6(1.9)$ & 0.300 \\
Video game & $0.4(1.0)$ & $0.2(0.6)$ & $0.7(1.2)$ & 0.000 \\
Computer & $0.3(0.8)$ & $0.3(0.6)$ & $0.3(1.0)$ & 0.080 \\
\hline Total & $3.3(2.5)$ & $3.1(2.2)$ & $3.6(1.9)$ & 0.000 \\
\hline
\end{tabular}


(a)

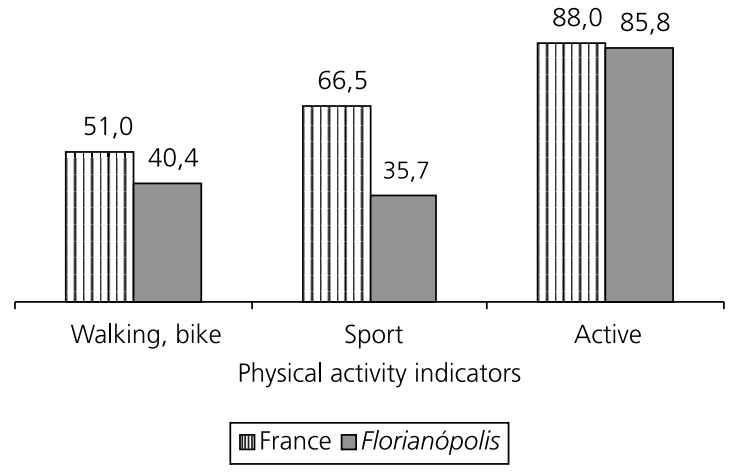

(b)

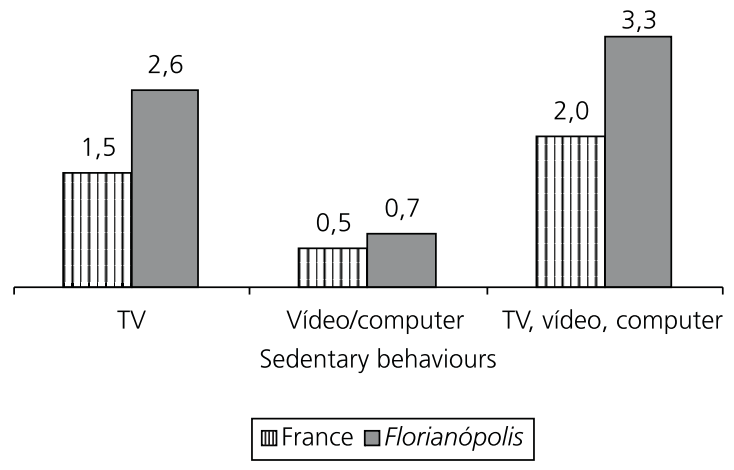

Figure 2. Physical activity indicators and parent's perception of the child's activity (a) and sedentary behaviors (b) (hours/typical weekday) in Florianópolis ( $n=1689$ ) and French children ( $n=1$ 147).

computer) in boys and girls from the Florianópolis' study. Boys spent more time playing video game than girls on a typical weekday.

Figure 2 compares the physical activity indicators (2a) and sedentary behaviors (2b) between French and Florianópolis' children, according to the parents' perception. A higher proportion of French children go to school walking or/and biking. The frequency of children performing a regular sport activity outside school in France was almost double the proportion observed in Florianópolis.

\section{DISCUSSION}

In the present study we presented the nutritional status in 7-9-y-old schoolchildren of Florianópolis city, using the BMI French references. The main objective was to compare overweight and thinness frequencies in children from Florianópolis with data from French children in the same age range, because a similar protocol was used in both studies. Data on physical activity and sedentary behaviors were presented and compared between the studies.

France and Brazil have different contexts in cultural and socioeconomic development and thus some epidemiologic indicators may differ markedly. In addition to the generally favorable rate of cardiovascular diseases, other interesting aspects of public health in France merit attention. This country has the longest life expectancy in the Western world (second only to Japan among developed countries) ${ }^{15}$. One very disturbing fact about the French nutrition and health situation is the recent steep increase of overweight prevalence in childhood. As the French references have been available for a long time, it was possible to compare data from $2000^{3}$ with previous values. In a study conducted in the same age range, the prevalence was $5.1 \%$ in $1980 ; 12.5 \%$ in $1996^{16}$ and it reached $16.3 \%$ in $2000^{3}$. Besides, thinness also seems to increase (3.0\% in 1965 and 3.9\% in 2000) $)^{4,6}$.

In Brazil, the prevalence of overweight in 6-9-y old children tripled in two decades (from $4.9 \%$ in 1974 to $17.4 \%$ in 1997), whereas underweight decreased $(12.3 \%$ in 1974 to $6.1 \%$ in 1997) ${ }^{17}$.

\section{Comparison between the Florianópolis and French study}

According to the French references, overweight was more frequent in the Florianópolis than in the French sample, while frequency of thinness was higher in France. Certain types of behaviors were less favorable in Florianópolis than in France and could contribute to this difference. French children had a higher level of physical 
activity (more walking, cycling, less television viewing) compared with children from Florianópolis. Environmental factors could contribute to some of the differences observed between the studies. First, in France, the school schedule is full time, whereas in Florianópolis (like in most Brazilian schools), children attend classes in the morning or in the afternoon. Thus, Florianópolis children were more exposed to leisure time on schooldays, and probably this time was often spent watching TV, playing video games and using a computer. Second, in France, public schools must be located preferentially near the children's home, whereas in Florianópolis distances from home to school are greater in most cases. Therefore, children spend more time in buses or cars. Third, in France, schoolchildren are encouraged to perform after school physical activities in public facilities. Besides, there are some programs, supported by public and private sectors, aimed at promoting sports activities for schoolchildren on week-ends, holydays and school breaks. In the past, Brazilian children used to play in open spaces around their homes, which are becoming less and less common due to the increased urbanization and overall violence.

Multivariate studies have found that television viewing and playing videogames for longer periods of time, or not participating in sports outside school, promotes obesity, whilst physical activity shows protective effects or no relationship ${ }^{18,19}$. Cross- sectional and prospective studies conducted with children in the USA ${ }^{20}$, Portugal ${ }^{21}$, Australia ${ }^{22}$, Mexico ${ }^{23}$ and Greece ${ }^{24}$ have found that hours of television viewing were closely associated with increased levels of obesity.

\section{Prevalence of overweight and obesity according to the International Obesity Task Force (IOTF) references in children from Florianópolis: comparison with other studies}

Santa Catarina's population is predominantly of European origin. The prevalence of overweight and obesity recorded in Florianópolis ${ }^{7}$ was compared with those reported for East Germany ${ }^{25}$, Italy ${ }^{26}$, Portugal ${ }^{27}$ and France ${ }^{3}$, according to the IOTF definition ${ }^{6}$ (Figure 3 ). The figure also shows the prevalence of overweight and obese children from the city of Rio de Janeiro ${ }^{28}$, the Northeastern and Southeastern Brazilian regions and the United States (NHANES III, 1988-1994) ${ }^{17}$. The prevalence of overweight in schoolchildren from Florianópolis city was higher than in the city of Rio de Janeiro ${ }^{28}$ and the Northeastern and Southeastern Brazilian regions ${ }^{17}$. Portugal, Italy and East Germany presented higher prevalence of overweight and obese children than France, USA and the Northeastern and Southeastern Brazilian regions.

The differences in prevalence of overweight and obesity should be interpreted considering the date of data collection, the study design, socioeconomic, environmental and lifestyle factors in different regions. Data from the city of Rio Janeiro ${ }^{28}$ was collected in the year 1999, in a representative sample of children and adolescents from public schools. Data from the city of Florianópolis ${ }^{7}$ was collected in the year 2002, in a representative sample of schoolchildren from public and private schools. In the present study, children from private schools presented higher prevalence of overweight and obesity when compared with children from public schools, according to the IOTF definition (data not shown). These data will be presented in a forthcoming paper. Data from the Florianópolis' study was collected five years after the National study ${ }^{17}$ and the age range was slightly different between the studies. The Southern Brazilian region presents better living standards than the Northeastern region (included in the National study) and probably eating, physical activities and sedentary behaviors differ between these regions.

\section{CONCLUSION}

Obesity frequency increases rapidly in many countries, particularly in children. This trend 


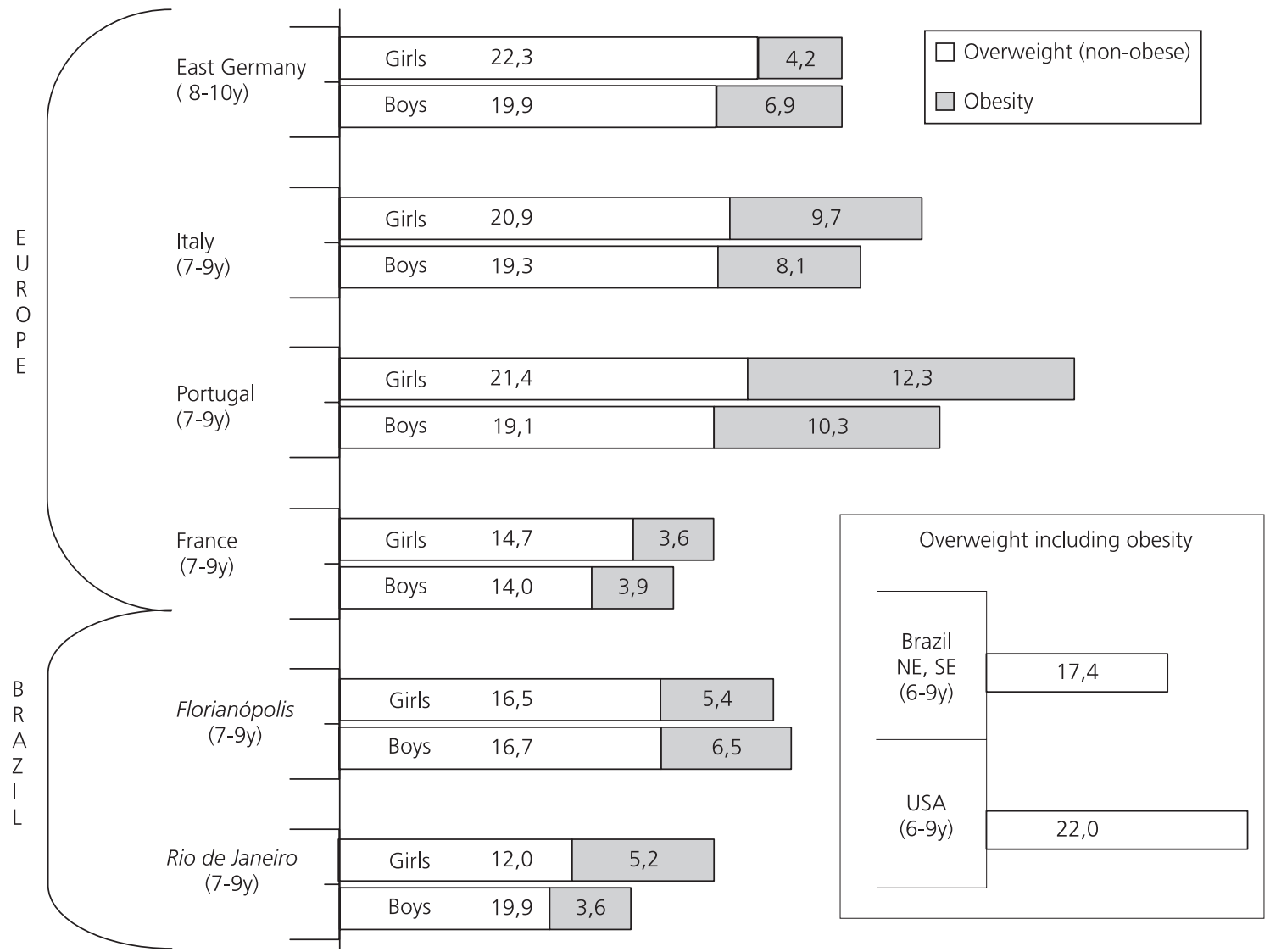

Figure 3. Frequencies of overweight and obese children in Brazil [Florianópolis (2002); Rio de Janeiro (1999); Northeastern and Southeastern regions (1997)], France (2000), Portugal (2002-2003), Italy (1993-2001), East Germany (1998-1999) and USA (1988-1994), using the IOTF definition ${ }^{6}$. (Year of data collection).

which appears in developing as well as in developed countries seems to have been accelerating in recent years. Child obesity is more and more often associated with pathologies that, until recently, were observed only in adults ${ }^{12}$.

While the increasing frequency of obesity is well established, its causes obviously originate from several changes in lifestyle, and in particular the decrease in physical activity and the change in the food offer. Comparing data obtained using similar methods in widely different contexts might allow risk factors to be identified more clearly.

The recent data on nutritional status in children from Florianópolis support the previously reported high frequencies of childhood overweight in developing countries undergoing a nutritional transition. While Brazilian nutrition programs aim at decreasing under-nutrition, Brazil has caught up with and even exceeded the overweight frequency of some European countries. In France, acknowledging the problem has stimulated reflection and has led to school interventions. Studies such as the present one carried out in a city from southern Brazil should allow a better assessment of current problems and allow adaptation measures to be taken in response to the rapid societal changes. International comparisons and the observation of similarities or differences between countries might lead to hypotheses about the critical factors in different contexts.

\section{ACKNOWLEDGMENTS}

This work has been carried out thanks to a post-doctoral scholarship from Coordenação de 
Aperfeiçoamento de Pessoal de Nivel Superior (CAPES) - MEC - Brazil, obtained by de Assis MAA, in 2003.

This study was sponsored by the Fundação de Apoio à Pesquisa Científica e Tecnológica do Estado de Santa Catarina (FAPESC); the Secretaria da Saúde and the Secretaria da Educação - Prefeitura Municipal de Florianópolis and the Universidade Federal de Santa Catarina (UFSC).

\section{REFERE NCES}

1. World Health Organization. Obesity: preventing and managing the global epidemic. Report of a WHO consultation on obesity. Geneva; 1998.

2. Lehingue Y. The European Child Obesity Group (ECOG) project: the European collaborative study on the prevalence of obesity in children. Am J Clin Nutr. 1999; 70(1):S166-8.

3. Rolland-Cachera MF, Castetbon K, Arnault N, Bellisle F, Romano MC, Lehingue $Y$, et al. Body Mass Index in 7 to 9 year-old French children: frequency of obesity, overweight, and thinness. Int J Obes Relat Metab Disord. 2002; 26(12):1610-6.

4. Castetbon K, Rolland-Cachera MF. Surpoids et obésité chez les enfants de 7 à 9 ans. Conservatoire des Arts et Métiers. Paris: Unité de Surveillance et d’Épidémiologie Nutritionnelle; 2000.

5. Must A, Dallal GE, Dietz WH. Reference data for obesity: 85th and 95th percentiles of body mass index (wt/ht2) and triceps skinfold thickness. Am J Clin Nutr. 1991; 53(4):839-46.

6. Cole TJ, Bellizi MC, Flegal KM, Dietz WH. Establishing a standard definition for child overweight and obesity worldwide: international survey. BMJ. 2000; 320(7244):1240-3.

7. Assis MA, Rolland-Cachera MF, Grosseman S, Vasconcelos FA, Luna ME, Calvo MC, et al. Obesity, overweight and thinness in schoolchildren of the city of Florianopolis, Southern Brazil. Eur J Clin Nutr. 2005; 59(9):1015-21.

8. Rolland-Cachera MF, Cole TJ, Sempé M, Tichet J, Rossignol C, Charraud A. Body Mass Index variations: centiles from birth to 87 years. Eur J Clin Nutr. 1991; 45(1):13-21.

9. Instituto de Pesquisas Econômicas Aplicadas. Atlas de Desenvolvimento Humano. Nota do IPEA sobre o Relatório do Desenvolvimento Humano 2002. Brasília; 2002.

10. Instituto Brasileiro de Geografia e Estatística [Internet]. Rio de Janeiro; 2002 [acesso 29 ago
2003]. Diretoria de Pesquisas, Coordenação de População e Indicadores Sociais. Pesquisa Nacional por Amostra de Domicílios, 2002. Disponível em: www.ibge.br

11. World Health Organization Expert Commitee. Physical status: the use and interpretation of anthropometry. Geneva; 1995. Technical Report Series, $n^{\circ} 854$.

12. Dietz WH, Robinson TN. Use of the body mass index (BMI) as a measure of overweight in children and adolescents. J Pediatr. 1998; 132(2):191-3.

13. Sempé M, Pédron G, Roy-Pernot MP. Auxologie, méthode et séquences. Paris: Théraplix; 1979.

14. Rolland-Cachera MF, Sempé M, Guilloud-Bataille M, Patois E, Péquignot-Guggenbuhl F, Fautrad V. Adiposity indices in children. Am J Clin Nutr. 1982; 36(1):178-84.

15. Bellisle F. Nutrition and health in France: dissecting a paradox. J Am Diet Assoc. 2005; 105(12): 1870-3.

16. Vol S, Tichet J, Rolland-Cachera MF. Trends in the prevalence of obesity between 1980 and 1996 among French adults and children. Int J Obesity. 1998; 22:S210.

17. Wang Y, Monteiro C, Popkin BM. Trends of obesity and underweight in older children and adolescents in the United States, Brazil, China, and Russia. Am J Clin Nutr. 2002; 75(6):971-7.

18. Berkey CS, Rockett HR, Field AE, Gillman MW, Frazier $A L$, Camargo CA Jr, et al. Activity dietary intake, and weight changes in a longitudinal study of preadolescent and adolescent boys and girls. Pediatrics. 2000; 105(4):E56.

19. O'Loughlin J, Gray-Donald K, Paradis G, Meshefedjian G. One- and two-year predictors of excess weight gain among elementary schoolchildren in multiethnic, low-income, innercity neighborhoods. Am J Epidemiol. 2000; 152(8):739-46.

20. Dietz WH Jr, Gortmaker SL. Do we fatten our children at the television set? Obesity and television viewing in children and adolescents. Pediatrics. 1985; 75(5):807-12.

21. Padez C, Mourão I, Moreira P, Rosado V. Prevalence and risk factors for overweight and obesity in Portuguese children. Acta Paediatr. 2005; 94(11):1550-7.

22. Wake M, Hesketh K, Waters E. Television, computer use and body mass index in Australian primary school children. J Paediatr Child Health. 2003; 39(2):130-4.

23. Hernandez B, Gortmaker SL, Colditz GA, Peterson KE, Laird NM, Parra-Cabrera S. Association of obesity with physical activity, television 
programmes and other forms of video viewing among children in Mexico city. Int J Obes. 1999; 23(8):845-54.

24. Krassas GE, Tzotzas T, Tsametis C, Konstantinidis T. Determinants of body mass index in Greek children and adolescents. J Pediatr Endocrinol Metab. 2001; 14(Suppl 5):1327-33.

25. Frye C, Heinrich J. Trends and predictors of overweight and obesity in East German children. Int J Obes Relat Metab Disord. 2003; 27(8):963-9.

26. Celi F, Bini V, De Giorgi G, Molinari D, Faraoni F, Di Stefano G, et al. Epidemiology of overweight and obesity among school children and adolescents in three provinces of central Italy, 1993-2001: study of potential influencing variables. Eur J Clin Nutr. 57(9):1045-51.

27. Padez C, Fernandes T, Mourão I, Moreira P, Rosado $V$. Prevalence of overweight and obesity in 7-9-year-old Portuguese children: trends in body mass index from 1970-2002. Am J Hum Biol. 2004; 16(6):670-8.

28. Anjos LA, Castro IR, Engstrom EM, Azevedo AM. Growth and nutritional status in a probabilistic sample of schoolchildren from Rio de Janeiro, 1999. Cad Saúde Pública. 2003; 19(Suppl 1):S171-9.

Submitted on: 24/4/2006 Approved on: 16/5/2006 